\title{
Nutrient balance in the soil and nutritive characteristics of maize silage cut at different heights
}

\section{Balanço de nutrientes no solo e características nutricionais da silagem de milho quando colhida em diferentes alturas}

\author{
Julio Hülse ${ }^{1 *}$; Mikael Neumann²; Robson Kyoshi Ueno ${ }^{3}$; Julio Cezar Heker Junior; \\ Danúbia Nogueira Figueira ${ }^{5}$; Itacir Eloi Sandini²; Marcelo Marques Lopes Müller²; \\ Egon Henrique Horst ${ }^{6}$; Gabriela Letícia Delai Vigne ${ }^{7}$
}

\begin{abstract}
Maize harvesting for silage promotes intense use of soil nutrients. The increase in forage harvesting time can ease nutrient use and benefit the nutritional quality of the silage. However, this practice may be economically unviable due to the reduction in the volume of harvested forage. The objective of our experiment was to evaluate several agronomic parameters, such as production, plant composition, nutritional value of silage and nutrient balance in the soil by harvesting the maize plant at different silage heights: $0.20 ; 0.40 ; 0.60 ; 0.80$ and $1.00 \mathrm{~m}$ above the ground. The experimental design was completely randomized, with five treatments with five repetitions. Representative plants in each plot were cut and fragmented in a forage machine. This material was homogenized and ensiled in experimental polyvinyl chloride (PVC) silos. Each $0.10 \mathrm{~m}$ increase at harvest provided an increase of $0.65 \%$ in the dry matter content of the forage and reduced harvest to $339 \mathrm{~kg} \mathrm{ha}^{-1}$ of dry matter. The presence of grains in the forage increased linearly $1.24 \%$ for every $0.10 \mathrm{~m}$ at the time of harvest. The levels of neutral detergent fiber, acid detergent fiber and silage lignin had a linear decrease of 4.5, 2.8 and 9.6\%, respectively, per each $0.10 \mathrm{~m}$ lift crop height. Regarding the total digestible nutrients, dry matter intake and the relative forage, these values had a linear increase of $0.5,7.2$ and $8.2 \%$, respectively. For each $0.10 \mathrm{~m}$ increase in cutting height, there was a decrease in soil nutrients, namely $3.6 \mathrm{~kg} \mathrm{ha}^{-1} \mathrm{~N}, 1.3 \mathrm{~kg} \mathrm{ha}^{-1} \mathrm{P}_{2} \mathrm{O}_{5}, 9.5 \mathrm{~kg} \mathrm{ha}^{-1}$ $\mathrm{K}_{2} \mathrm{O}, 0.9 \mathrm{~kg} \mathrm{ha}^{-1} \mathrm{CaO}$ and $1.2 \mathrm{~kg} \mathrm{ha}^{-1} \mathrm{MgO}$. Even with the harvest at $1.00 \mathrm{~m}$ above the ground, nutrient recycling nutrients by necromass is not sufficient to balance the potassium balance in the soil, causing a decline of $37.69 \mathrm{~kg} \mathrm{ha}^{-1} \mathrm{~K}_{2} \mathrm{O}$. The maize harvest to $0.47 \mathrm{~m}$ height represented the best relationship between silage quantity and quality, being the height that presents the greatest potential for economic return, and can fund management practices and soil fertilization to prevent degradation in foraging systems, mainly to overcome the negative balance of potassium in the system.
\end{abstract}

\footnotetext{
${ }^{1}$ M.e, Programa de Pós-Graduação em Agronomia, Universidade Estadual do Centro-Oeste, UNICENTRO, Guarapuava, PR, Brasil.E-mail: julioh@agraria.com.br

2 Profs., Programa de Pós-Graduação em Agronomia, UNICENTRO, Guarapuava, PR, Brasil. E-mail: neumann.mikael@hotmail. com; isandini@hotmail.com; mmuller@unicentro.br

3 Dr., Programa de Pós-Graduação em Zootecnia, Universidade Federal do Rio Grande do Sul, UFRGS, Porto Alegre, RS, Brasil. E-mail: robsonueno@hotmail.com

${ }^{4}$ Discente de Doutorado, Programa de Pós-Graduação em Agronomia, UNICENTRO, Guarapuava, PR, Brasil. E-mail: jr_heker@ hotmail.com

5 Discente de Doutorado, Programa de Pós-Graduação em Zootecnia da Universidade Estadual Paulista Júlio de Mesquita Filho, UNESP, Jaboticabal, SP, Brasil. E-mail: danmedvet07@gmail.com

${ }_{6}$ Discente de Doutorado, Programa de Pós-Graduação em Ciência Animal da Universidade Estadual de Londrina, UEL, Londrina, PR, Brasil. E-mail: egonhh@yahoo.com.br

7 Discente de Mestrado, Programa de Pós-Graduação em Ciências Veterinárias, UNICENTRO, Guarapuava, PR, Brasil. E-mail: gabriela.vigne@yahoo.com.br

* Author for ocrrespondence
} 
Key words: Nutrient use. Harvest time. Potassium. Silage quality.

\section{Resumo}

A colheita de milho para ensilagem promove intensa exportação de nutrientes do solo. A elevação da altura de colheita da forragem pode amenizar a exportação de nutrientes e beneficiar a qualidade nutricional da silagem. No entanto, essa prática pode ser inviável economicamente devido à redução no volume de forragem colhida. Objetivou-se com este experimento avaliar os parâmetros agronômicos de produção, composição vegetal, valor nutricional da silagem e balanço de nutrientes no solo pela colheita da planta de milho em diferentes alturas: 0,$20 ; 0,40 ; 0,60 ; 0,80$ e $1,00 \mathrm{~m}$ do solo. $\mathrm{O}$ delineamento experimental foi inteiramente casualizado, composto por 5 tratamentos com 5 repetições. Plantas representativas de cada parcela foram colhidas nas respectivas alturas e fragmentadas em uma ensiladeira. Este material foi homogeneizado e ensilado em silos experimentais de policloreto de vinila (PVC). Cada 0,10 m de elevação na altura de colheita proporcionou aumento de 0,65 pontos percentuais no teor de matéria seca da forragem e redução da colheita de $339 \mathrm{~kg} \mathrm{ha}^{-1}$ de fitomassa seca. A participação de grãos na forragem acresceu linearmente na ordem de 1,24 pontos percentuais a cada $0,10 \mathrm{~m}$ de elevação na altura de colheita. Os teores de fibra em detergente neutro, fibra em detergente ácido e lignina da silagem apresentaram decréscimo linear de 4,$5 ; 2,8$ e 9,6\%, respectivamente, a cada $0,10 \mathrm{~m}$ de elevação da altura de colheita; enquanto que os nutrientes digestíveis totais, o consumo de matéria seca e o valor relativo da forragem tiveram acréscimo linear de 0,$5 ; 7,2$ e $8,2 \%$, respectivamente. A cada $0,10 \mathrm{~m}$ de elevação da altura de colheita, houve redução da exportação de nutrientes do solo na ordem de: $3,6 \mathrm{~kg}$ $\mathrm{ha}^{-1}$ de $\mathrm{N} ; 1,3 \mathrm{~kg} \mathrm{ha}^{-1}$ de $\mathrm{P}_{2} \mathrm{O}_{5} ; 9,5 \mathrm{~kg} \mathrm{ha}^{-1}$ de $\mathrm{K}_{2} \mathrm{O} ; 0,9 \mathrm{~kg} \mathrm{ha}^{-1}$ de $\mathrm{CaO}$ e 1,2 $\mathrm{kg} \mathrm{ha}^{-1}$ de MgO. Mesmo com a colheita a $1,00 \mathrm{~m}$ do solo, a reciclagem de nutrientes pela necromassa não é suficiente para equilibrar o balanço de potássio no solo, causando déficit de $37,69 \mathrm{~kg} \mathrm{ha}^{-1}$ de $\mathrm{K}_{2} \mathrm{O}$. A colheita do milho a $0,47 \mathrm{~m}$ de altura representa a melhor relação entre quantidade e qualidade da silagem, sendo a altura que apresenta maior potencial de retorno econômico, e pode custear práticas de manejo e fertilização do solo para impedir sua degradação em sistemas de forrageamento, principalmente no intuito de suprir o balanço negativo de potássio no sistema.

Palavras-chave: Altura de colheita. Exportação de nutrientes. Potássio. Qualidade da silagem.

\section{Introduction}

Brazil grows more than 15 million hectares of maize per year, with between 10 and $15 \%$ of the maize-planted area intended for the production of whole plant silage for animal feed (CONAB, 2015). The height at which the maize plant is cut for harvest is an important decision for silage production.

The closer the cutting height is to the spike, the higher the energetic and nutritional values of maize silage, due to the high concentration of grains. Indeed, a higher cutting height improves the dry matter (DM) digestibility of the silage, even in commercial cultivars considered to have high cell wall digestibility, as reported by Caetano et al. (2012) in an evaluation of maize cultivars for silage, harvested at $0.05 \mathrm{~m}$ above the ground or
$0.05 \mathrm{~m}$ below the first spike insertion. Thus, silage harvested at higher plant heights is favored for use with high production animals (NUSSIO et al., 2001a).

Harvesting the plant closer to the spike also increases organic matter recycling in the soil and the return of some of the nutrients concentrated in the lower internodes of the plant, as these become necromass instead of being harvested. Maize production requires high amounts of soil nutrients: whereas necromass decomposition after grain harvesting interferes with the nutrient balance of the soil via the nutrient cycle, this does not happen if the entire plant is harvested for silage production (UENO et al., 2013). In particular, harvesting high may reduce potassium deficiency in the soil caused 
by forage harvesting, as the highest concentrations of this nutrient are in the culm (NEUMANN et al., 2007; UENO et al., 2013). Most silage producers cultivate maize with the fertilizer rates recommended for grain production, causing nitrogen and, especially, potassium deficits (UENO et al., 2013). Improper soil management and nutrient replenishment may rapidly reduce soil fertility in areas used for silage production, particularly if this persists for several consecutive years (MARTIN et al., 2011).

On the other hand, increasing the cutting height poses a risk for lower economic return, due to the lower dry biomass harvested per hectare. Furthermore, an evaluation of soil nutrient content for six consecutive years in a silage production area, using organic fertilizer with the return of manure from the fed animals, found that it was not possible to prevent potassium deficiency in the soil (SILVA et al., 2010). This study also reported a reduction of the electrical conductivity of the soil, possibly caused by the reduction of ions over the years, and no significant phosphorus mobilization.

Thus, the effects of manipulating the cutting height of the forage should be analyzed in a program of rational land exploitation aiming for high productivity, and deserve a more careful economic evaluation to justify the recommendations (NUSSIO et al., 2001b). Increasing the height of forage harvesting may be a useful strategy reduce or ameliorate the intense depletion of some nutrients from the soil, while also resulting in improved silage quality, through the greater accumulation of necromasses in the soil. Accordingly, this study evaluated the effect of different harvested heights of the maize plant for silage on the production and quality of silage, and assessed nutrient balance in the soil and the economic result of the system.

\section{Materials and Methods}

The experiment was conducted at Unicentro Universidade Estadual do Centro-Oeste (Paraná State University of the Central West) at Guarapuava, in the subtropical zone of the State of Paraná, Brazil (MAACK, 2002), at an elevation of 1.023 $\mathrm{m}$. The climate of the region is classified as type $\mathrm{Cfb}$ (KÖPPEN). The mean annual maximum and minimum temperatures are $23.5^{\circ} \mathrm{C}$ and $12.7^{\circ} \mathrm{C}$, respectively, with an annual average rainfall of $1944 \mathrm{~mm}$ (IAPAR, 2000). The mean values of precipitation and temperature occurring in the period of maize culture are shown in Figure 1.

Figure 1. Average temperature and accumulated precipitation, for each 10-day period, during the growing season of the maize crop in 2011/2012, Guarapuava, PR, Brazil.

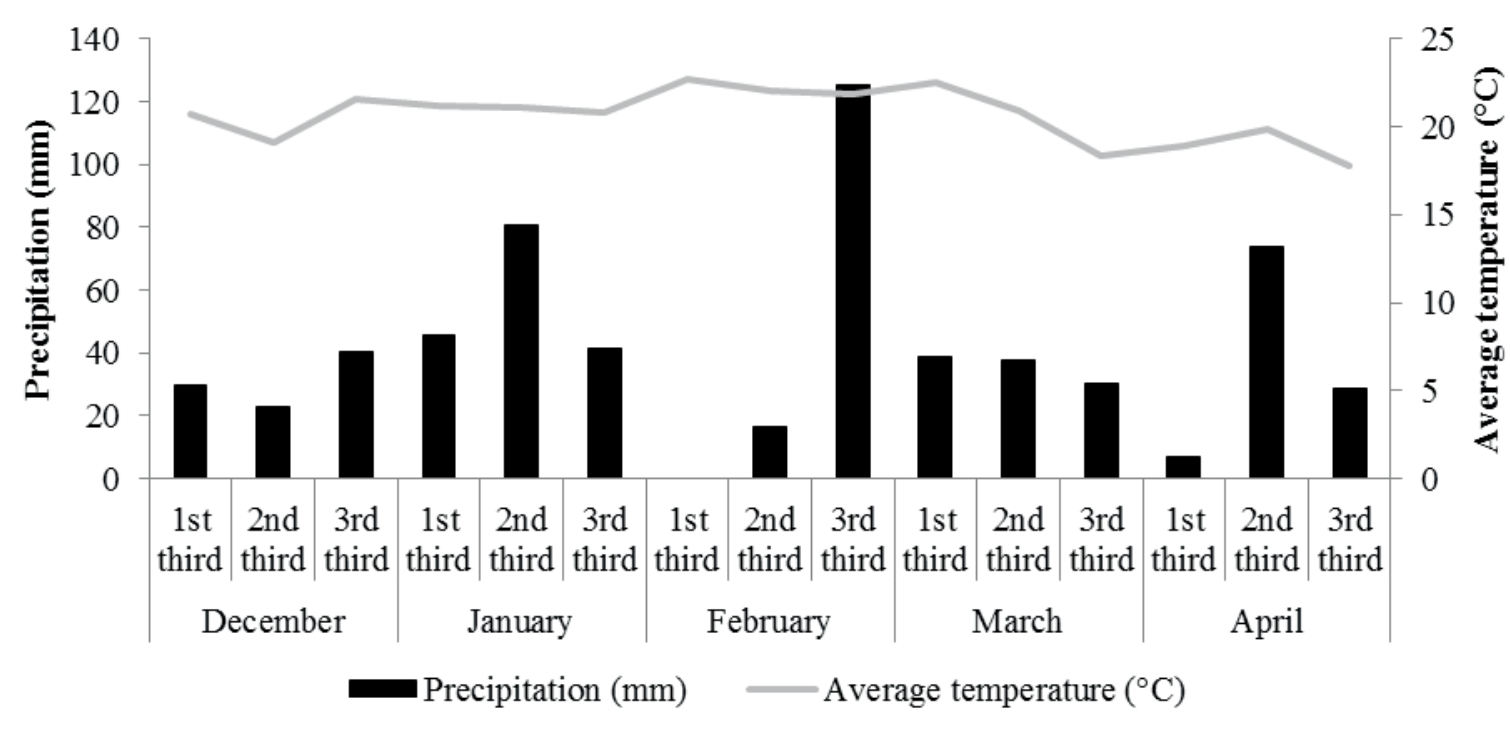


The plots were established in the soil classified by Embrapa (2006) as Latossolo Bruno, in an area with a history of crop-livestock rotation and previously used with oats and ryegrass cover. The soil analysis indicated: $\mathrm{pH} \mathrm{CaCl}_{2} 0.01 \mathrm{~mol} \mathrm{dm}^{-3} 4.5$; P: $4.4 \mathrm{mg} \mathrm{dm}^{-3} ; \mathrm{K}^{+}: 0.5 \mathrm{cmolc} \mathrm{dm}^{-3}$; organic matter: 4.15\%; $\mathrm{Al}^{3+}$ : $0.15 \mathrm{cmolc} \mathrm{dm}^{-3} ; \mathrm{H}^{+} \mathrm{Al}: 6.99 \mathrm{cmol} \mathrm{dm}^{-}$ 3. $\mathrm{Ca}^{2+}: 2.8 \mathrm{cmolc} \mathrm{dm}^{-3}$ and $\mathrm{Mg}^{2+}: 2.2$ cmolc dm${ }^{-3}$.

We evaluated the effects of five harvested heights of maize plants for silage. The experimental design was completely randomized, consisting of five treatments and five replicates. Harvest heights were $0.20,0.40,0.60,0.80$ and $1.00 \mathrm{~m}$ above ground level.

The P30F53HR (Pioneer $\left.{ }^{\circledR}\right)$ maize hybrid, a silage-granular, precocious and medium-sized maize crop, was planted in a no-tillage system in an area of $720 \mathrm{~m}^{2}$, which was divided into 25 plots with 6 lines of width and $6 \mathrm{~m}$ of length each. During the sowing, a row spacing of $0.8 \mathrm{~m}$, a seed depth of $0.04 \mathrm{~m}$ and a distribution of 6 seeds per linear meter were used.

In the no-tillage system, $300 \mathrm{~kg} \mathrm{ha}^{-1}$ of the formulated fertilizer 05-25-25 $\left(\mathrm{N}-\mathrm{P}_{2} \mathrm{O}_{5}-\mathrm{K}_{2} \mathrm{O}\right)$ were applied, and after 30 days of plant growth, cover fertilization was carried out with $200 \mathrm{~kg} \mathrm{ha}^{-1}$ of $\mathrm{N}$ (urea). In the crop management, $4.0 \mathrm{~L} \mathrm{ha}^{-1}$ of herbicide with active ingredient atrazine and tembotrione $240 \mathrm{~mL} \mathrm{ha}^{-1}$ were applied. Also, 150 $\mathrm{mL} \mathrm{ha-1}$ of insecticide of the pyrethroid chemical group was applied.

The collection of the phytometric data of maize plants was carried out at the phenological stage of farinaceous grain to hard grain, at 134 days after plant emergence. During this assessment, plants of each plot were harvested and manually cut at soil level. Plant height, shoot height, stem insertion height, stalk diameter, number of dry leaves and plant weight were evaluated. The plants were then cut at the height corresponding to each treatment, for separation and weighing of the ensilable phytomass (part of the plant that will be ensiled) and of the remaining phytomass (lower stem that is not ensiled). The fresh and dry phytomass production was estimated by the relation between the final population (plants ha ${ }^{-1}$ ) and the average weight per plant. In order to determine the population of plants per hectare, the plants contained in 5 random linear meters of each plot were counted.

The morphological components were manually separated in stem, leaves, bracts plus cob, grains and remaining phytomass. Five representative plants of each plot were fragmented in a stationary forage machine, with a mean particle size of 1.8 $\mathrm{cm}$. The material was homogenized and ensiled in experimental PVC silos with a diameter of $0.10 \mathrm{~m}$ and $0.55 \mathrm{~m}$ in length, equipped with a cap containing a Bunsen valve for gassing. During the filling of the silos, the final specific mass was adjusted to $750 \mathrm{~kg}$ $\mathrm{m}^{-3}$ of forage. After 85 days of the ensiling process, the silos were opened for analysis.

Samples of the plant structures and silages were weighed and pre-dried in a forced air circulation oven at $55^{\circ} \mathrm{C}$ until achieving a constant weight for the analysis of the partial dry matter (DM) content, according to AOAC (1995). As DM content is obtained by greenhouse dehydration methods, the values were corrected according to the equation suggested by Porter and Murray (2001). The dried samples were milled in a Willey type mill with a 1 $\mathrm{mm}$ sieve.

We assessed the crude protein (CP) by the micro Kjeldahl method, mineral matter (MM) by incineration at $550^{\circ} \mathrm{C}(4 \mathrm{~h})$ and ethereal extract (EE) according to AOAC (1995). The neutral detergent fiber (NDF) contents, were analyzed using thermostable $\alpha$-amylase (Termamyl ${ }^{\circledR} 120 \mathrm{~L}$, Novozymes ${ }^{\circledR}$ Latin America Ltd.) according to Van Soest et al. (1991), and fiber in acid detergent (FAD) according to Goering and Van Soest (1970). Lignin contents were determined by the Silva e Queiroz (2009) method and hemicellulose by the equation hemicellulose $=$ NDF - ADF. We also calculated cellulose (cellulose $=$ ADF - lignin) and the non- 
fibrous carbohydrate content $[\mathrm{NFC}=100-(\mathrm{CP}$ $+\mathrm{EE}+\mathrm{MM}+\mathrm{NDF})]$. To determine the total dry matter, samples were dried in an oven at $105^{\circ} \mathrm{C}$ for 16 hours, and then weighed (SILVA; QUEIROZ, 2009). N, P, K, Ca and Mg levels were determined according to Tedesco et al. (1995).

The total digestible nutrient contents (TDN) of the silages were calculated according to the equations proposed by Weiss et al. (1992). The relative food value (RFV) was expressed by the association between the potential DM consumption and the estimated dry matter digestibility (DMD): $\mathrm{RFV}=[(\mathrm{DMD} \times(120 \div \mathrm{NDF}) \div 1.29]$, according to Bolsen (1996). Milk production per metric ton of DM and per hectare was simulated with the help of the MILK 2006 worksheet, developed by Shaver et al. (2006).

To perform cost analysis, we carried out a survey on the cost of components with average values practiced in the State of Paraná. When assessing the expenses of crop development, such as machine operation (192.91 R\$ ha ${ }^{-1}$ ), fixed and temporary labor (48.90 R\$ ha-1), seed value (472.45 R\$ ha-1) and expenditures with pesticides (503.61 $\left.\mathrm{R} \$ \mathrm{ha}^{-1}\right)$, we considered the results of the cost estimates for the high-tech production of maize, with a yield of $8,500 \mathrm{~kg} \mathrm{ha}^{-1}$ grains for the harvest in the 2016/2017 summer in the state of Paraná (CONAB, 2016a). However, the values spent on fertilizers used in basic fertilization (05-25-25; $\left.429.69 \mathrm{R} \$ \mathrm{ha}^{-1}\right)$ and cover fertilization (45-00-00; 643.86 $\left.\mathrm{R} \$ \mathrm{ha}^{-1}\right)$, were obtained by the average practiced in the first half of 2016, according to Conab (2016b).

Harvesting and storage costs $\left(1,710.52 \mathrm{R} \$ \mathrm{ha}^{-1}\right)$ of maize in the form of forage were considered as the technical coefficients of the process, according to Embrapa (2003). The values paid for the services were computed according to Paraná (2016), considering that the ensiling of 1 ha of maize forage requires: $3.88 \mathrm{~h}$ of tractor service ( 71 to $86 \mathrm{HP}$ ) and one-row sawing for cutting and mincing at a cost of $106.63 \mathrm{RS} \mathrm{h}^{-1} ; 8.0 \mathrm{~h}$ of tractor service (50 to 70 HP) for the transportation of the chopped forage, distribution in the silo and compacting costing 88.75 $\mathrm{R} \$ \mathrm{~h}^{-1} ; 4.74$ man-days of work for forage unloading and distribution, aid in the field and to the tractor driver, at a cost of $95.00 \mathrm{R} \$ \mathrm{~d}^{-1}$; and $70 \mathrm{~m}^{2}$ of $150 \mu$ double-sided canvas, with a regional average price of $1.95 \mathrm{R} \$ \mathrm{~m}^{-2}$.

The total cost $\left(\mathrm{R} \$ \mathrm{t}^{-1}\right.$ of $\left.\mathrm{DM}\right)$ was obtained by summing the silage production costs per hectare divided by DM production of each harvest height. For the calculation of the total cost with the replacement of nutrients in the soil, the nutrients contained in the remaining biomass were transformed from the total cost per metric ton of DM, converted to monetary values by the equivalents in urea ( $45 \%$ of $\left.\mathrm{N} ; 1,448.69 \mathrm{R} \$ \mathrm{t}^{-1}\right)$, simple superphosphate (18\% of $\left.\mathrm{P}_{2} \mathrm{O}_{5} ; 1,081.04 \mathrm{R}^{-1} \mathrm{t}^{-1}\right)$ and potassium chloride $(60 \%$

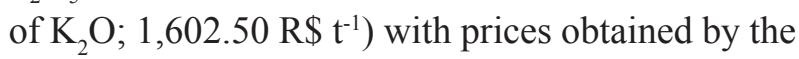
average practiced in the first half of 2016, according to the consultation carried out in the agricultural indicators of Conab (2016b). The commercial formulas of the fertilizers were obtained by the following calculation, according to CQFS RS/ SC (2004): $\mathrm{P}_{2} \mathrm{O}_{5}=\mathrm{P} \times 2.29, \mathrm{~K}_{2} \mathrm{O}=\mathrm{K} \times 1.20, \mathrm{CaO}=\mathrm{Ca}$ $\times 1.39$ and $\mathrm{MgO}=\mathrm{Mg} \times 1.66$.

Data were subjected to regression analysis, considering the variable plant height, using the PROC REG procedure of the statistical program SAS (1993). The analysis of each variable followed the statistical model: $Y i j=\mu+A C i+E i j$, in which Yij = dependable variables; $\mu=$ overall mean of all observations; $\mathrm{ACi}=$ effect of harvest height of order "i", in which $1=0.20 \mathrm{~m}, 2=0.40 \mathrm{~m}, 3=0.60 \mathrm{~m}, 4=$ $0.80 \mathrm{~m}$ and $5=1.00 \mathrm{~m}$; Eij $=$ residual random error.

\section{Results and Discussion}

The cutting height influenced the amount of ensilableandremaining phytomass ofmaizeproduced (Figure 2). At cutting height, the maize hybrid was, on average $2.02 \mathrm{~m}$ tall, with a spike insertion at 1.12 $\mathrm{m}$ on average, and a productive potential of 53,045 $\mathrm{kg} \mathrm{ha}^{-1}$ of fresh ensilable phytomass and $15,979 \mathrm{~kg}$ ha $^{-1}$ of dry ensilable phytomass. With the increase 
in cutting height, fresh and dry ensilable phytomass yields decreased linearly, with reductions of $9.6 \%$ and $9.8 \%$, respectively, for each $0.10 \mathrm{~m}$ increase in cutting height.

Figure 2. Productions of fresh and dry ensilable phytomass and remaining fresh and dried phytomass from the maize crop subjected to different cutting heights for ensiling.

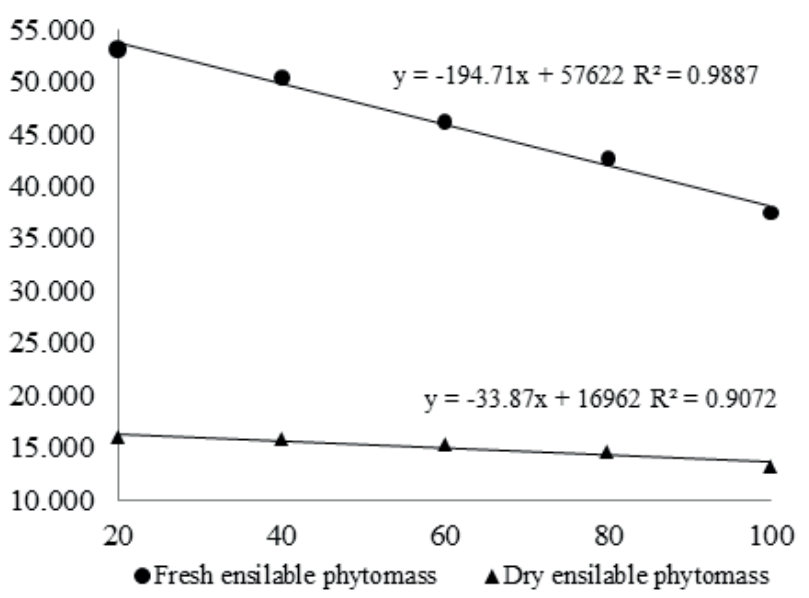

${ }^{* * *} \mathrm{P}<0.01 ;{ }^{* *} \mathrm{P}<0.05 ;{ }^{*} \mathrm{P}<0.10 ;{ }^{\mathrm{ns}}=$ not significant.

Neumann et al. (2007) observed a $10.3 \%$ reduction in the production of fresh ensilable phytomass after increasing the cutting height from $0.15 \mathrm{~m}$ to $0.39 \mathrm{~m}$, whereas the production of dry ensilable phytomass decreased by $6.6 \%$ (from 19,144 to $17,875 \mathrm{~kg} \mathrm{ha}^{-1}$ of DM). Oliveira et al. (2011) observed a $13.6 \%$ reduction in the yield of ensilable phytomass (from 14,600 to $12,600 \mathrm{~kg} \mathrm{ha}^{-1}$ of DM) after increasing the harvesting height from $0.15 \mathrm{~m}$ to $0.55 \mathrm{~m}$. Similar values were also found by Lauer (1998) and Castañeda et al. (2005), who observed reductions of dry phytomass of $15 \%$ and $13 \%$ with the increase in the cutting height from 0.15 $\mathrm{m}$ to $0.45 \mathrm{~m}$, respectively. Juremtchuk et al. (2006), who studied cutting heights of $0.20 \mathrm{~m}$ or $0.40 \mathrm{~m}$, observed a reduction of $12.9 \%$ in dry biomass.

The fresh and dry remaining phytomasses increased linearly by $2,270 \mathrm{~kg} \mathrm{ha}^{-1}$ and $546 \mathrm{~kg}$ $\mathrm{ha}^{-1}$ for each $0.10 \mathrm{~m}$ increase in cutting height, respectively (Figure 2). Neumann et al. (2007) observed an increase of $1,226 \mathrm{~kg} \mathrm{ha}^{-1}$ in the dry remaining phytomass production after increasing

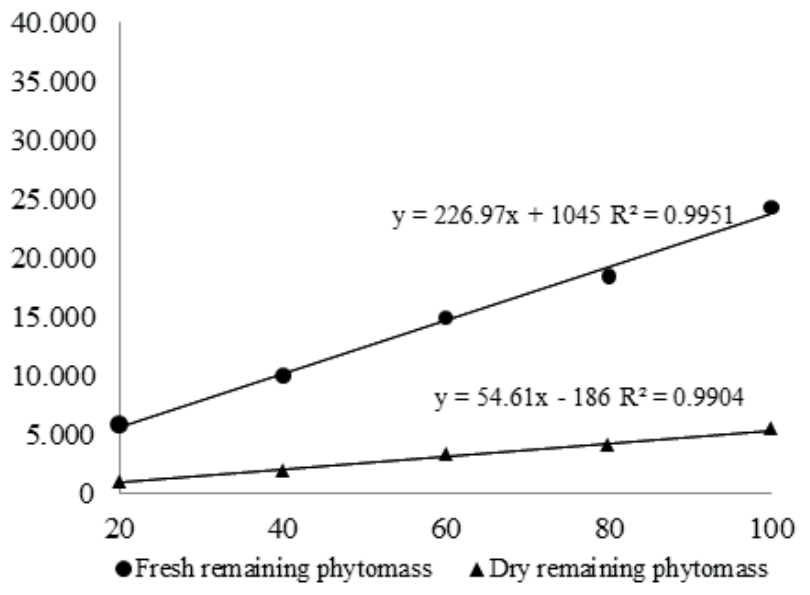

the cutting height of $0.15 \mathrm{~m}$ to $0.39 \mathrm{~m}$.

The DM content of ensilable and remaining phytomass increased linearly by 0.65 and $0.68 \%$ for each $0.10 \mathrm{~m}$ increase in the cutting height, respectively. Cutting height had no influence on DM contents of the culm, leaves, bracts and grains (Table 1), as the hybrid and the culture used were similar between treatments. These results indicate that the bottom stem is the component with the highest moisture content in the plant (about 80\%), and its participation in the phytomass interferes with the DM content of the silage. Pedó et al. (2009) found a similar effect of cutting height on DM, reporting a linear increase of $0.69 \%$ for each $0.10 \mathrm{~m}$ increase in cutting height, when evaluating the effect of 4 cutting heights $(0.20,0.45,0.70$ and $0.95 \mathrm{~m})$. On the other hand, Juremtchuk et al. (2006) found DM contents of $31.7 \%$ and $33.9 \%$ in the phytomass harvested at $0.20 \mathrm{~m}$ or $0.40 \mathrm{~m}$, respectively, a change of $1.1 \%$ per $0.10 \mathrm{~m}$ increase in cutting height. 
Table 1. Dry matter content (\%) of the structural components of the plant, ensilable phytomass and remaining maize crop subjected to different cutting heights for ensiling.

\begin{tabular}{|c|c|c|c|c|c|c|c|}
\hline \multirow{2}{*}{ Parameters } & \multicolumn{6}{|c|}{ Cutting heights $(\mathrm{cm})$} & \multirow{2}{*}{ Regression equations } \\
\hline & 20 & 40 & 60 & 80 & 100 & Mean & \\
\hline Culm & 22.4 & 23.9 & 24.6 & 22.8 & 24.6 & 23.7 & $\hat{y}=$ Not significant \\
\hline Leaves & 30.6 & 31.4 & 32.6 & 28.7 & 29.4 & 30.5 & $\hat{y}=$ Not significant \\
\hline Bracts and sticks & 37.6 & 34.0 & 34.6 & 34.0 & 34.5 & 34.9 & $\hat{y}=$ Not significant \\
\hline Grains & 64.2 & 62.8 & 63.3 & 60.8 & 62.4 & 62.7 & $\hat{y}=$ Not significant \\
\hline Ensilable phytomass & 30.2 & 31.2 & 33.0 & 34.2 & 35.2 & 32.7 & $\begin{array}{c}\hat{\mathrm{y}}=28.82 * * *+0.065 * * * \mathrm{x} \\
\left(\mathrm{CV}: 3.31 \% ; \mathrm{R}^{2}: 0.76 ; \mathrm{P}=0.0001\right)\end{array}$ \\
\hline Remaining phytomass & 16.6 & 18.8 & 22.1 & 21.5 & 22.1 & 20.2 & $\begin{array}{c}\hat{y}=16.13 * * *+0.068^{* * * x} \\
\left(\mathrm{CV}: 7.36 \% ; \mathrm{R}^{2}: 0.65 ; \mathrm{P}=0.0001\right)\end{array}$ \\
\hline
\end{tabular}

${ }^{* * *} \mathrm{P}<0.01 ;{ }^{* *} \mathrm{P}<0.05 ;{ }^{*} \mathrm{P}<0.10 ;{ }^{\text {ns }}=$ not significant.

Regarding the structural components of the plant (Table 2), there was a linear reduction in the percentage of stem and leaves, whereas the percentage of grains and bracts increased more linearly as the cutting height increased. The stem and leaf ratio decreased 1.0 and $0.4 \%$, respectively, for each $0.10 \mathrm{~m}$ increase. On the other hand, the grains had increase phytomass, representing $47 \%$ in the harvest done at $0.20 \mathrm{~m}$ and $57.2 \%$ in the harvest done at $1.00 \mathrm{~m}$. The bracts and cob showed greater stability in participation, ranging from $19.4 \%$ to $21.7 \%$.

Table 2. Morphological composition (\%) of maize biomass subjected to different cutting heights for ensiling.

\begin{tabular}{|c|c|c|c|c|c|c|c|}
\hline \multirow{2}{*}{ Parameters } & \multicolumn{6}{|c|}{ Cutting heights $(\mathrm{cm})$} & \multirow{2}{*}{ Regression equations } \\
\hline & 20 & 40 & 60 & 80 & 100 & Mean & \\
\hline Culm & 13.9 & 11.3 & 9.8 & 7.3 & 5.5 & 9.6 & $\begin{array}{c}\hat{y}=15.83^{* * *}-0.105^{* * *} \mathrm{x} \\
\left(\mathrm{CV}: 10.31 \% ; \mathrm{R}^{2}: 0.91 ; \mathrm{P}=0.0001\right)\end{array}$ \\
\hline Leaves & 18.9 & 18.1 & 17.6 & 16.3 & 15.6 & 17.3 & $\begin{array}{c}\hat{y}=19.82 * * *-0.042 * * * x \\
\left(C V: 8.87 \% ; R^{2}: 0.40 ; P=0.0007\right)\end{array}$ \\
\hline Bracts and sticks & 20.2 & 19.4 & 20.5 & 20.9 & 21.7 & 20.5 & $\begin{array}{c}\hat{y}=19.18^{* * *}+0.023^{* *} \mathrm{x} \\
\left(\mathrm{CV}: 7.55 \% ; \mathrm{R}^{2}: 0.16 ; \mathrm{P}=0.0502\right)\end{array}$ \\
\hline Grains & 47.0 & 51.2 & 52.2 & 55.6 & 57.2 & 52.6 & $\begin{array}{c}\hat{\mathrm{y}}=45.18^{* * *}+0.124 * * * \mathrm{x} \\
\left(\mathrm{CV}: 4.92 \% ; \mathrm{R}^{2}: 0.67 ; \mathrm{P}=0.0001\right)\end{array}$ \\
\hline
\end{tabular}

${ }^{* * *} \mathrm{P}<0.01 ;{ }^{* *} \mathrm{P}<0.05 ;{ }^{*} \mathrm{P}<0.10 ;{ }^{\text {ns }}=$ not significant.

Grain yields in the phytomass, even at the lowest harvest, were higher than those found by Paziani et al. (2009), in which grains represented $35.6 \%$ of the DM and culm corresponded to $27.1 \%$ of the DM. Neumann et al. (2007), who studied a higher cutting height $(0.15 \mathrm{~m}$ versus $0.39 \mathrm{~m})$, observed higher yields in terms of leaves (28.4\% vs $28.9 \%)$ and cobs (39.6\% vs $43.7 \%)$, and a lower yield of culm $(32.0 \%$ vs. $27.8 \%$ ). A similar response was found by Restle et al. (2002a) (27.6\% to $30.8 \%)$, who observed a higher yield in terms of leaves (27.6\% para $30.8 \%$ ) and cobs (45.0\% to $47.4 \%$ ), and a lower yield of culm $(27.4 \%$ to $21.8 \%)$ in the phytomass harvested at two heights $(0.20 \mathrm{~m}$ to $0.42 \mathrm{~m})$.

The increase in the cutting height caused a linear reduction in the production of CP, TDN, NDF, HEM, FAD, CEL, LIG and MM in the ensilable phytomass (Table 3). For each $0.10 \mathrm{~m}$ increase, there was a 
decrease of 22.2, 128.0, 297.3, 140.2, 157.0, 119.5, 37.6 and $29.3 \mathrm{~kg} \mathrm{ha}^{-1}$, respectively. This contrasts with reports by Oliveira et al. (2011), who did not observe differences in EE and $\mathrm{CP}$ production with the increase in cutting height from $0.15 \mathrm{~m}$ to $0.55 \mathrm{~m}$, and Vasconcelos et al. (2005), who also did not find differences in CP yields $\left(\mathrm{kg} \mathrm{ha}^{-1}\right)$ in the ensilable phytomass. However, both described a reduction of $24 \%$ in NDF and $29 \%$ in the FAD, with an increase in the cutting height from $0.10 \mathrm{~m}$ to $0.80 \mathrm{~m}$.

Table 3. Nutritional compound yields $\left(\mathrm{kg} \mathrm{ha}^{-1}\right)$ in the ensilable maize phytomass at differeng cutting heights.

\begin{tabular}{|c|c|c|c|c|c|c|c|}
\hline \multirow{2}{*}{ Parameters } & \multicolumn{6}{|c|}{ Cutting heights $(\mathrm{cm})$} & \multirow{2}{*}{ Regression equations } \\
\hline & 20 & 40 & 60 & 80 & 100 & Mean & \\
\hline $\mathbf{C P}$ & 1,256 & 1,228 & 1,156 & 1,136 & 1,080 & 1,171 & $\begin{array}{c}\hat{y}=1304.50 * * *-2.22 * * * x \\
\left(\mathrm{CV}: 9.67 \% ; \mathrm{R}^{2}: 0.25 ; \mathrm{P}=0.0108\right)\end{array}$ \\
\hline TDN & 9,919 & 10,067 & 9,963 & 9,663 & 8,841 & 9,691 & $\begin{array}{c}\hat{y}=10458.00^{* * *}-12.80 * * * x \\
\left(C V: 10.08 \% ; R^{2}: 0.13 ; P=0.0768\right)\end{array}$ \\
\hline $\mathbf{E E}$ & 448 & 456 & 444 & 430 & 366 & 429 & $\hat{y}=N S$ \\
\hline NFC & 5,177 & 5,280 & 5,681 & 5,723 & 5,151 & 5,402 & $\hat{y}=N S$ \\
\hline NDF & 8,483 & 8,195 & 7,435 & 6,865 & 6,175 & 7,431 & $\begin{array}{c}\hat{y}=9214.76^{* * *}-29.73 * * * x \\
\left(C V: 9.70 \% ; R^{2}: 0.60 ; P<0.0001\right)\end{array}$ \\
\hline HEM & 4,527 & 4,415 & 4,120 & 3,760 & 3,452 & 4,055 & $\begin{array}{c}\hat{y}=4896.36^{* * *}-14.02 * * * x \\
\left(C V: 12.25 \% ; R^{2}: 0.41 ; P=0.0006\right)\end{array}$ \\
\hline ADF & 3,956 & 3,780 & 3,315 & 3,105 & 2,723 & 3,376 & $\begin{array}{c}\hat{\mathrm{y}}=4318.20^{* * *}-15.71 * * * \mathrm{x} \\
\left(\mathrm{CV}: 8.92 \% ; \mathrm{R}^{2}: 0.70 ; \mathrm{P}<0.0001\right)\end{array}$ \\
\hline CEL & 3,252 & 3,224 & 2,804 & 2,612 & 2,363 & 2,851 & $\begin{array}{c}\hat{y}=3568.06^{* * *}-11.95^{* * *} \mathrm{x} \\
\left(\mathrm{CV}: 9.63 \% ; \mathrm{R}^{2}: 0.62 ; \mathrm{P}<0.0001\right)\end{array}$ \\
\hline LIG & 704 & 556 & 511 & 493 & 360 & 525 & $\begin{array}{c}\hat{y}=750.36 * * *-3.76 * * * x \\
\left(C V: 22.01 \% ; R^{2}: 0.48 ; P<0.0001\right)\end{array}$ \\
\hline MM & 615 & 560 & 489 & 436 & 384 & 497 & $\begin{array}{c}\hat{y}=672.54 * * *-2.93 * * * x \\
\left(C V: 14.62 \% ; R^{2}: 0.58 ; P<0.0001\right)\end{array}$ \\
\hline
\end{tabular}

$\mathrm{CP}=$ Crude Protein $(\%$ in DM $) ; \mathrm{TDN}=$ Total Digestible Nutrients $(\%$ in DM $) ; \mathrm{EE}=$ Ethereal extract $(\%$ in DM $) ; \mathrm{NFC}=\mathrm{Non}-$ fibrotic carbohydrates $(\%$ in DM $)$; NDF $=$ Neutral Detergent Fiber $(\%$ in DM $)$; HEM $=$ Hemicellulose $(\%$ in DM $)$; FAD $=$ Fiber in Detergent Acid (\% in DM); CEL = Cellulose ( $\%$ in DM $) ; \mathrm{LIG}=$ Lignin $(\%$ in DM $) ; \mathrm{MM}=$ Mineral Matter $(\%$ in DM $)$;

${ }^{* * *} \mathrm{P}<0.01 ; \mathrm{NS}=$ not significant.

Nutrient depletion from the soil through biomass harvesting also displayed a linear decrease with increasing cutting heights (Table 4). According to silage analysis, nutrient extraction followed the decreasing order $\mathrm{N}>\mathrm{K}>\mathrm{P}>\mathrm{Mg}>\mathrm{Ca}$. Meanwhile, in the remaining phytomass, nutrient retention increased linearly with cutting height, and in the decreasing order, $\mathrm{K}>\mathrm{N}>\mathrm{Mg}>\mathrm{Ca}>\mathrm{P}$. Thus, $\mathrm{K}$ concentration was highest in the bottom of the stem, whereas $\mathrm{P}$ was most concentrated in the upper part of the plant (Table 5). Oliveira (2009), investigating
3 cutting heights $(0.15,0.35$ and $0.55 \mathrm{~m})$, observed mineral retention in the remaining phytomass in the decreasing order $\mathrm{K}>\mathrm{N}>\mathrm{Ca}>\mathrm{P}$. In the same study, the authors found $\mathrm{K}$ levels of $14.15 \mathrm{ha}^{-1}, 27.89 \mathrm{ha}^{-1}$ and $49.62 \mathrm{ha}^{-1} ; \mathrm{N}$ levels of $5.12 \mathrm{ha}^{-1}, 10.68 \mathrm{ha}^{-1}$ and 18.11 $\mathrm{ha}^{-1}$, according to the respective cutting heights. $\mathrm{Ca}$ and $\mathrm{P}$ presented values below 5 ha-1, even at the highest cutting height.

DM, CP, EE, NFC, TDN and the RFV of the silage responded linearly to increasing cutting heights (Table 6). These results are consistent with 
those presented by Pedó et al. (2009), who observed a linear increase of $3.5 \%$ in EE content for each $0.10 \mathrm{~m}$ of cutting height. Also, Kung Junior et al. (2008) observed a 4\% increase in CP content when harvested at $0.48 \mathrm{~m}$ compared to $0.13 \mathrm{~m}$. In contrast, Oliveira et al. (2011) did not find differences in CP and EE contents after harvesting at $0.15,0.35$ or $0.55 \mathrm{~m}$.

Table 4. Depletion of nutrients from the soil (kg ha-1) through the ensilable maize biomass subjected to cutting heights for ensiling.

\begin{tabular}{|c|c|c|c|c|c|c|c|}
\hline \multirow{2}{*}{ Parameters } & \multicolumn{6}{|c|}{ Cutting heights $(\mathrm{cm})$} & \multirow{2}{*}{ Regression equations } \\
\hline & 20 & 40 & 60 & 80 & 100 & Mean & \\
\hline $\mathbf{N}$ & 200.9 & 196.5 & 185.0 & 181.7 & 172.8 & 187.4 & $\begin{array}{c}\hat{y}=208.69^{* * *}-0.355^{* * * x} x \\
\left(C V: 9.67 \% ; R^{2}: 0.25 ; P=0.0108\right)\end{array}$ \\
\hline $\mathbf{P}$ & 24.0 & 24.8 & 23.3 & 21.3 & 20.1 & 22.7 & $\begin{array}{c}\hat{y}=26.13 * * *-0.057 * * x \\
\left(C V: 14.65 \% ; R^{2}: 0.20 ; P=0.0234\right)\end{array}$ \\
\hline $\mathbf{K}$ & 154.6 & 138.3 & 116.4 & 101.8 & 93.9 & 121.0 & $\begin{array}{c}\hat{y}=168.37 * * *-0.789 * * * x \\
\left(C V: 17.13 \% ; R^{2}: 0.56 ; P<0.0001\right)\end{array}$ \\
\hline $\mathrm{Ca}$ & 16.6 & 15.4 & 13.9 & 13.1 & 11.4 & 14.1 & $\begin{array}{c}\hat{y}=17.94 * * *-0.064 * * * x \\
\left(C V: 12.36 \% ; R^{2}: 0.54 ; P<0.0001\right)\end{array}$ \\
\hline Mg & 24.4 & 24.1 & 22.2 & 20.1 & 19.1 & 22.0 & $\begin{array}{c}\hat{y}=26.36 * * *-0.073 * * * x \\
\left(\mathrm{CV}: 10.49 \% ; \mathrm{R}^{2}: 0.47 ; \mathrm{P}=0.0002\right)\end{array}$ \\
\hline
\end{tabular}

$\mathrm{N}=$ Nitrogen $\mathrm{P}=$ Phosphorus $\mathrm{K}=$ Potassium; $(\mathrm{Ca})$ = Calcium; $\mathrm{Mg}=$ Magnesium;

${ }^{* * *} \mathrm{P}<0.01 ;{ }^{* *} \mathrm{P}<0.05$

Table 5. Retention of nutrients in the remaining biomass $\left(\mathrm{kg} \mathrm{ha}^{-1}\right)$ of maize subjected to cutting heights for silage.

\begin{tabular}{|c|c|c|c|c|c|c|c|}
\hline \multirow{2}{*}{ Parameters } & \multicolumn{6}{|c|}{ Cutting heights $(\mathrm{cm})$} & \multirow{2}{*}{ Regression equations } \\
\hline & 20 & 40 & 60 & 80 & 100 & Mean & \\
\hline $\mathbf{N}$ & 3.07 & 8.94 & 15.97 & 22.96 & 36.00 & 17.39 & $\begin{array}{c}\hat{\mathrm{y}}=-6.575^{* * *}+0.399 * * * \mathrm{x} \\
\left(\mathrm{CV}: 20.61 \% ; \mathrm{R}^{2}: 0.92 ; \mathrm{P}<0.0001\right)\end{array}$ \\
\hline $\mathbf{P}$ & 0.23 & 0.55 & 0.99 & 1.70 & 2.58 & 1.21 & $\begin{array}{c}\hat{\mathrm{y}}=-0.543 * * *+0.029 * * * \mathrm{x} \\
\left(\mathrm{CV}: 28.54 \% ; \mathrm{R}^{2}: 0.86 ; \mathrm{P}<0.0001\right)\end{array}$ \\
\hline $\mathbf{K}$ & 11.15 & 20.69 & 36.25 & 56.84 & 66.81 & 38.35 & $\begin{array}{c}\hat{y}=-5.888^{*}+0.737 * * * x \\
\left(C V: 22.40 \% ; R^{2}: 0.86 ; P<0.0001\right)\end{array}$ \\
\hline Ca & 1.09 & 3.35 & 5.80 & 6.86 & 12.2 & 5.86 & $\begin{array}{c}\hat{y}=-1.864^{* *}+0.129^{* * *} \mathrm{x} \\
\left(\mathrm{CV}: 30.66 \% ; \mathrm{R}^{2}: 0.82 ; \mathrm{P}<0.0001\right)\end{array}$ \\
\hline Mg & 2.24 & 4.38 & 6.15 & 6.98 & 11.51 & 6.25 & $\begin{array}{c}\hat{y}=-0.085^{\text {ns }}+0.106^{* * *} \mathrm{x} \\
\left(\mathrm{CV}: 25.69 \% ; \mathrm{R}^{2}: 0.79 ; \mathrm{P}<0.0001\right)\end{array}$ \\
\hline
\end{tabular}

$\mathrm{N}=$ Nitrogen; $\mathrm{P}=$ Phosphorus $; \mathrm{K}=$ Potassium; $(\mathrm{Ca})=$ Calcium; $\mathrm{Mg}=$ Magnesium;

${ }^{* * *} \mathrm{P}<0.01 ;{ }^{* *} \mathrm{P}<0.05 ;{ }^{*} \mathrm{P}<0.10 ;{ }^{\text {ns }}=$ not significant.

The NFC, a fraction represented by mono- and disaccharides, starch and soluble fiber, increased by $1.7 \%$ with each $0.10 \mathrm{~m}$ increase in the cutting height. These values are higher than those found by Pedó et al. (2009), which reported an increase of $0.7 \%$ for each $0.10 \mathrm{~m}$ increase. The mean values of NFC (34.4\%) for 29 maize silages, according to Valadares Filho et al. (2006), are 25\% smaller than the lowest cut $(0.20 \mathrm{~m})$ presented in our work.

The NDF, FAD and HEM levels decreased linearly as the cutting height increased, by 1.9, 0.6 and $1.3 \%$, respectively, for each $0.10 \mathrm{~m}$ increase in the height (Table 6). This was similar to the $0.8 \%$ reduction in NDF and $0.7 \%$ reduction in FAD with each $0.10 \mathrm{~m}$ increase in cutting height reported by 
Pedó et al. (2009) when comparing 5 cutting heights, but contrasted with the $13.24 \%$ reduction of in the NDF content reportd by Restle et al. (2002a), cutting at 0.20 and $0.42 \mathrm{~m}$. Oliveira et al. (2011) observed a $8.7 \%$ reduction in the NDF content and a $4.9 \%$ reduction in the FAD content after increasing the cutting height from $0.15 \mathrm{~m}$ to $0.35 \mathrm{~m}$. Kung Junior et al. (2008) observed a reduction of 8 and $9 \%$ for NDF and FAD, respectively, from 0.13 to $0.48 \mathrm{~m}$. Restle et al. (2002b), in studies with sorghum, also found that increasing the cutting height from 0.14 to $0.45 \mathrm{~m}$ changed the quality of the fibrous fraction of the silage, providing a reduction of 18.51 and $10.41 \%$ in the NDF and FAD contents, respectively.

Table 6. Nutritional characteristics of maize silages harvested at different cutting heights.

\begin{tabular}{|c|c|c|c|c|c|c|c|}
\hline \multirow{2}{*}{ Parameters } & \multicolumn{6}{|c|}{ Cutting heights $(\mathrm{cm})$} & \multirow{2}{*}{ Regression equations } \\
\hline & 20 & 40 & 60 & 80 & 100 & Mean & \\
\hline MS & 37.61 & 37.22 & 39.31 & 38.85 & 40.75 & 38.75 & $\begin{array}{c}\hat{y}=36.38^{* * *}+0.0395^{* * *} \mathrm{x} \\
\left(\mathrm{CV}: 4.61 \% ; \mathrm{R}^{2}: 0.29 ; \mathrm{P}=0.0048\right)\end{array}$ \\
\hline $\mathbf{C P}$ & 6.38 & 6.52 & 7.11 & 7.32 & 7.31 & 6.93 & $\begin{array}{c}\hat{y}=6.13 * * *+0.0133 * * * x \\
\left(C V: 3.48 \% ; R^{2}: 0.72 ; P=0.0001\right)\end{array}$ \\
\hline $\mathbf{E E}$ & 3.60 & 3.90 & 4.01 & 4.49 & 4.77 & 4.16 & $\begin{array}{c}\hat{y}=3.28 * * *+0.0146 * * * x \\
\left(C V: 8.26 \% ; R^{2}: 0.61 ; P=0.0001\right)\end{array}$ \\
\hline NFC & 45.95 & 45.87 & 52.52 & 55.59 & 57.69 & 51.53 & $\begin{array}{c}\hat{y}=41.56^{* * *}+0.1660^{* * * x} x \\
\left(C V: 6.47 \% ; R^{2}: 0.68 ; P=0.0001\right)\end{array}$ \\
\hline NDF & 41.08 & 40.84 & 33.66 & 29.92 & 27.57 & 34.61 & $\begin{array}{c}\hat{y}=46.00^{* * *}-0.1898^{* * * x} \\
\left(\mathrm{CV}: 8.91 \% ; \mathrm{R}^{2}: 0.77 ; \mathrm{P}=0.0001\right)\end{array}$ \\
\hline HEM & 21.77 & 21.19 & 15.31 & 13.81 & 12.15 & 16.85 & $\begin{array}{c}\hat{y}=24.83 * * *-0.1331 * * * x \\
\left(C V: 13.62 \% ; R^{2}: 0.74 ; P=0.0001\right)\end{array}$ \\
\hline FAD & 19.31 & 19.65 & 18.35 & 16.11 & 15.41 & 17.77 & $\begin{array}{c}\hat{y}=21.16^{* * *}-0.05663^{* * * x} \mathrm{x} \\
\left(\mathrm{CV}: 9.56 \% ; \mathrm{R}^{2}: 0.49 ; \mathrm{P}=0.0001\right)\end{array}$ \\
\hline CEL & 13.93 & 15.03 & 15.99 & 14.09 & 13.78 & 14.56 & $\hat{y}=$ Not significant \\
\hline LIG & 5.38 & 4.62 & 2.36 & 2.02 & 1.63 & 3.20 & $\begin{array}{c}\hat{y}=6.23 * * *-0.0505^{* * *} \mathrm{x} \\
\left(\mathrm{CV}: 45.10 \% ; \mathrm{R}^{2}: 0.51 ; \mathrm{P}=0.0001\right)\end{array}$ \\
\hline TDN & 65.89 & 67.58 & 72.96 & 75.06 & 76.68 & 71.63 & $\begin{array}{c}\hat{y}=62.92 * * *+0.1453 * * * x \\
\left(C V: 3.56 \% ; R^{2}: 0.74 \mathrm{P}=0.0001\right)\end{array}$ \\
\hline MM & 2.99 & 2.86 & 2.7 & 2.68 & 2.67 & 2.78 & $\begin{array}{c}\hat{y}=3.02^{* * *}-0.0041^{* *} \mathrm{x} \\
\left(\mathrm{CV}: 9.21 \% ; \mathrm{R}^{2}: 0.18 ; \mathrm{P}=0.0332\right)\end{array}$ \\
\hline Ca & 0.11 & 0.11 & 0.11 & 0.09 & 0.08 & 0.10 & $\begin{array}{c}\hat{y}=0.12 * * *-0.0004 * * * x \\
\left(C V: 14.65 \% ; R^{2}: 0.40 ; P=0.0007\right)\end{array}$ \\
\hline $\mathbf{P}$ & 0.16 & 0.15 & 0.16 & 0.16 & 0.16 & 0.16 & $\hat{y}=$ Not significant \\
\hline Mg & 0.17 & 0.18 & 0.17 & 0.14 & 0.14 & 0.16 & $\begin{array}{c}\hat{\mathrm{y}}=0.20^{* * *}-0.0006^{* * *} \mathrm{x} \\
\left(\mathrm{CV}: 11.09 \% ; \mathrm{R}^{2}: 0.51 ; \mathrm{P}=0.0001\right)\end{array}$ \\
\hline $\mathbf{K}$ & 0.63 & 0.61 & 0.60 & 0.63 & 0.59 & 0.61 & $\hat{y}=$ Not significant \\
\hline RFV & 167.26 & 167.99 & 209.59 & 240.62 & 260.87 & 209.27 & $\begin{array}{c}\hat{y}=131.33^{* * *}+1.2989^{* * *} \mathrm{x} \\
\left(\mathrm{CV}: 11.26 \% ; \mathrm{R}^{2}: 0.73 ; \mathrm{P}=0.0001\right)\end{array}$ \\
\hline
\end{tabular}

$\mathrm{CP}=$ Crude Protein $(\%$ in DM); EE = Ethereal extract $(\%$ in DM $) ; \mathrm{NFC}=$ Non-fibrotic carbohydrates $(\%$ in DM $) ; \mathrm{NDF}=$ Fiber in Neutral Detergent $(\%$ in DM); FAD = Fiber in Acid Detergent $(\%$ in DM $) ;$ CEL $=$ Cellulose $(\%$ in DM $) ;$ LIG $=$ Lignin $(\%$ in DM $)$; $\mathrm{TDN}=$ Total Digestible Nutrients $(\%$ in DM); $\mathrm{MM}=$ Mineral Matter $(\%$ in DM); $\mathrm{Ca}=$ Calcium $(\%$ in $\mathrm{DM}) ; \mathrm{P}=\mathrm{Phosphorus}(\%$ in $\mathrm{DM}) ; \mathrm{Mg}=$ Magnesium $(\%$ in DM $) ; \mathrm{K}=$ Potassium (\% in DM); EDMC = Estimated Dry Matter Consumption (\% do live weight); $\mathrm{RFV}=$ Relative Food Value (Index).

${ }^{* * *} \mathrm{P}<0.01 ;{ }^{* *} \mathrm{P}<0.05 ;{ }^{*} \mathrm{P}<0.10 ;{ }^{\text {ns }}=$ not significant. 
Lignin is one of the main factors that limits cell wall degradability (VAN SOEST, 1994). It also requires a longer time for rumen emptying, decreasing consumption. In the present work, lignin content declined $8.8 \%$ for each $0.10 \mathrm{~m}$ increase in cutting height, such that silage cut at $1.00 \mathrm{~m}$ had $70 \%$ less lignin than silage cut at $0.20 \mathrm{~m}$. Pedó et al. (2009) reported a 38.5\% lower lignin content in silage harvested at 0.95 compared to those cut at 0.20 . Oliveira et al. (2011) observed a reduction of $5.5 \%$ in the cutting height from $0.35 \mathrm{~m}$ to 0.55 $\mathrm{m}$. Kung Junior et al. (2008) observed a reduction of $13 \%$ after a height increase from 0.13 to $0.48 \mathrm{~m}$.

NFC content (sugars, starch, soluble fiber and organic acids) grew and fibrous components diminished with cutting height, due to increased grain concentration in the silage. Consequently, cutting height had a positive linear effect on the TDN and RFV indexes (Table 6), with a cutting height increase from 0.20 to $1.00 \mathrm{~m}$ corresponding to a $16.4 \%$ rise in silage TDN (from 65.9 to $76.7 \%$ ), whereas RFV increased by $13 \%$ for each 0.10 $\mathrm{m}$ cutting height increase. Oliveira et al. (2011) observed a less marked increase in the TDN value $(6.7 \%)$ after an increase in the cutting height from $0.15 \mathrm{~m}$ to $0.55 \mathrm{~m}$. Conversely, $\mathrm{MM}, \mathrm{Ca}$ and $\mathrm{Mg}$ decreased linearly with cutting height (Table 6).

Crop fertilization employed $215 \mathrm{~kg} \mathrm{ha}^{-1}$ of $\mathrm{N}$, $75 \mathrm{~kg} \mathrm{ha}^{-1}$ of $\mathrm{P}_{2} \mathrm{O}_{5}$ and $75 \mathrm{~kg} \mathrm{ha}^{-1}$ of $\mathrm{K}_{2} \mathrm{O}$ for all treatments (Figure 3). Nutrient extraction through the phytomass (total nutrients extracted from the soil in the aerial part of the plants) was similar among treatments for all nutrients, with average extraction in the decreasing order $\mathrm{N}>\mathrm{K}_{2} \mathrm{O}>\mathrm{P}_{2} \mathrm{O}_{5}>\mathrm{MgO}>\mathrm{CaO}$, corresponding to $204.77,191.23,54.76,46.84$ and $27.72 \mathrm{~kg} \mathrm{ha}^{-1}$, respectively. As the cutting height increased, nutrient depletion through the phytomass (nutrients effectively removed from the soil) decreased linearly for all nutrients. For each 0.10 $\mathrm{m}$ increase in height, depletion decreased by $3.6 \mathrm{~kg}$ $\mathrm{ha}^{-1}$ of $\mathrm{N}, 1.3 \mathrm{~kg} \mathrm{ha}^{-1}$ of $\mathrm{P}_{2} \mathrm{O}_{5}, 9.5 \mathrm{~kg} \mathrm{ha}^{-1} \mathrm{~K}_{2} \mathrm{O}, 0.9$ $\mathrm{kg} \mathrm{ha}^{-1} \mathrm{CaO}$ and $1.2 \mathrm{~kg} \mathrm{ha}^{-1}$ of $\mathrm{MgO}$. These values are similar to those reported by Ueno et al. (2013), evaluating nutrient depletion in a maize crop for silage. Thus, the imbalance caused by the extraction of nutrients through the phytomass was mitigated by nutrient recycling through the replacement of the remaining phytomass in the soil. For every $0.10 \mathrm{~m}$ of cutting height increase, there was a linear increase in soil replacement of $8.9 \mathrm{~kg} \mathrm{ha}^{-1}$ of $\mathrm{K}_{2} \mathrm{O}, 3.9 \mathrm{~kg} \mathrm{ha}^{-1}$ of $\mathrm{N}, 1.8 \mathrm{~kg} \mathrm{ha}^{-1}$ of $\mathrm{CaO}, 1.8$ $\mathrm{kg} \mathrm{kg} \mathrm{ha-1}$ of $\mathrm{MgO}$, and $0.7 \mathrm{~kg} \mathrm{ha}^{-1}$ of $\mathrm{P}_{2} \mathrm{O}_{5}$ (Figure 3). The highest remaining nutrients, in descending order, were $\mathrm{K}_{2} \mathrm{O}>\mathrm{N}>\mathrm{CaO}>\mathrm{MgO}>\mathrm{P}_{2} \mathrm{O}_{5}$. These results are consistent with Ritchie et al. (2003), who found the highest concentration of $\mathrm{K}$ in the vegetative structures of the plant $30 \%$ in the culm, $10 \%$ in the leaf sheaths, $10 \%$ in the lower insertion straws and ears and 5\% in the leaves), whereas $\mathrm{N}$ and $\mathrm{P}$ concentrate in the grains $(65 \%$ and $75 \%$, respectively). Therefore, the culm is one of the main compartments accumulating $\mathrm{K}$ in the maturity stage of the plant.

The assessment of nutrient replacement through the remaining phytomass showed the final nutrient balance in the soil. The final nitrogen and phosphorus soil balance was positive for all cutting heights. On the other hand, even with the highest cut $(1.00 \mathrm{~m})$, the remaining nutrient was not enough to balance $\mathrm{K}_{2} \mathrm{O}, \mathrm{CaO}$ and $\mathrm{MgO}$ levels in the soil, with negative values of $37.7,15.8$ and $31.7 \mathrm{~kg} \mathrm{ha}^{-1}$, respectively. It is important to note that the values of $\mathrm{CaO}$ and $\mathrm{MgO}$ were not considered in the soil via fertilization (Figure 3).

Nutrient extraction from the soil depends on the phytomass yield and on the accumulation of nutrients in the structural components. For plants to have access to the amount of nutrients they need, soil nutrients must be replaced, by either organic or mineral fertilizers, according to the balance between the depletion through phytomass and replacement via the remaining phytomass (VON PINHO et al., 2009). Thus, it is possible that the need for fertilization changes according to the cutting height of the forage. In this study, with a cutting height of the hybrid (P30F53HRR) at $0.20 \mathrm{~m}$ from the soil, 
a population of 68,854 plants ha $^{-1}$ and a depletion of $15,979 \mathrm{~kg} \mathrm{ha}^{-1}$ of DM, we would need 200, $55 \mathrm{e}$ $185 \mathrm{~kg} \mathrm{ha}^{-1}$ of $\mathrm{N}, \mathrm{P}_{2} \mathrm{O}_{5}$ and $\mathrm{K}_{2} \mathrm{O}$, respectively. Each $0.10 \mathrm{~m}$ increase in cutting height would reduce this requirement by 4,1 e $10 \mathrm{~kg} \mathrm{ha}^{-1}$ for $\mathrm{N}, \mathrm{P}_{2} \mathrm{O}_{5}$ and $\mathrm{K}_{2} \mathrm{O}$, respectively (Figure 3).

The economic analysis of the treatments (Table 7) indicated a cost of 4,001.94 $\mathrm{R} \$ \mathrm{ha}^{-1}$ for the preparation of silages. In a simulation of nutrient replacement via the remaining phytomass, the nutrients in the remaining phytomass were subtracted in amounts equivalent to urea, simple superphosphate and potassium chloride, to estimate the cost of production. The cost of production of silage corrected for nutrient replenishment in this simulation decreased linearly by $40.48 \mathrm{R} \$ \mathrm{ha}^{-1}$ for each $0.10 \mathrm{~m}$ increase in the cutting height. Thus, without considering the replacement of nutrients via the remaining phytomass, the cost of DM silage increased by $6.60 \mathrm{R} \$ \mathrm{t}^{-1}$ of $\mathrm{DM}$ for each $0.10 \mathrm{~m}$ increase in the cutting height; with nutrient replacement via the remaining phytomass, the cost increase for each $0.10 \mathrm{~m}$ increase in the cutting height was $3.50 \mathrm{R} \$ \mathrm{t}^{-1}$.

Figure 3. Nutrient balance in the soil after maize cultivation for silage at different cutting heights.
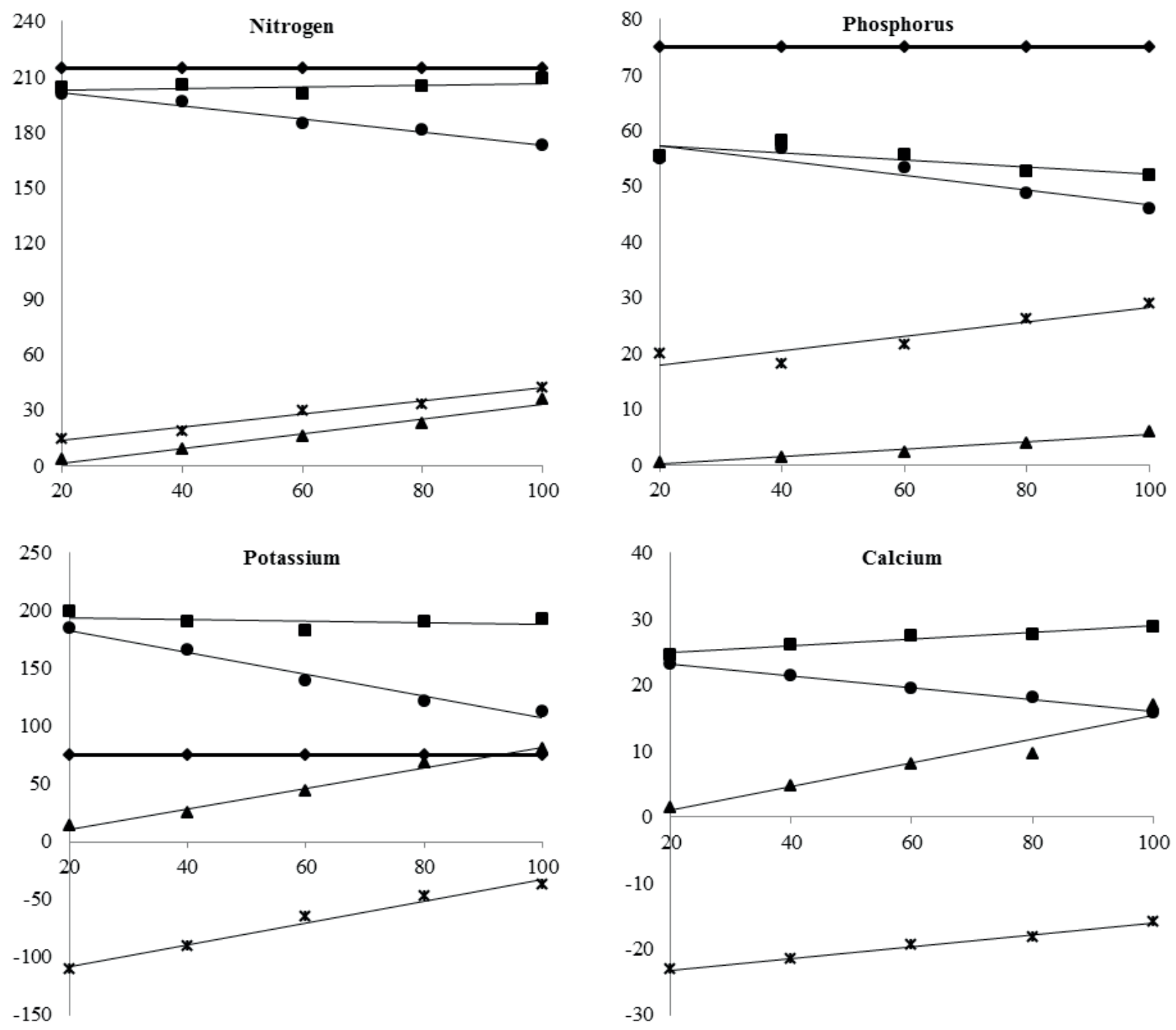

Continue... 
Continuation...

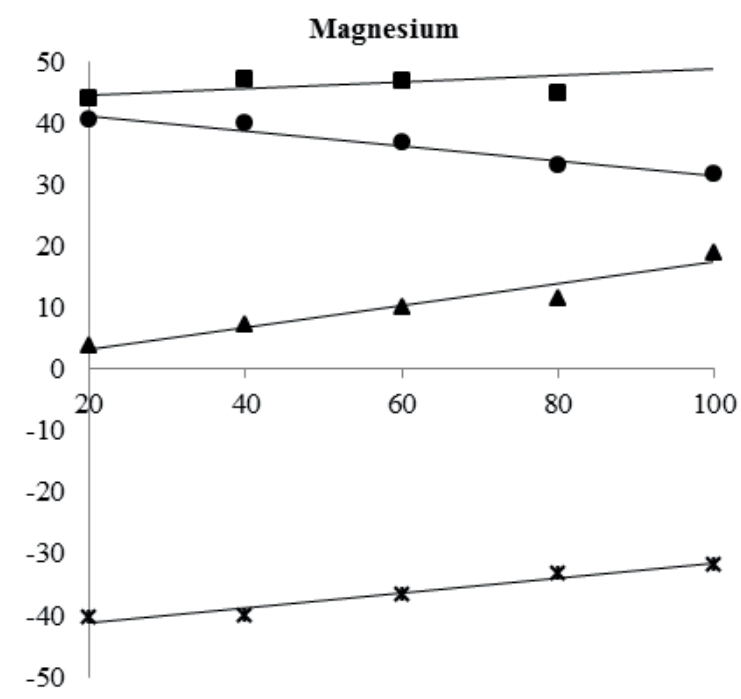

Legend

$\longrightarrow$ Nutrients provided via fertilization (F)

- Nutrients extracted by total biomass (E)

- Nutrients contained in the remaining phytomass (R)

- Nutrients depleted by the ensilable phytomass $(\mathrm{Ex}=\mathrm{E}-\mathrm{R})$

* Nutrient balance in the soil $(\mathrm{S}=\mathrm{F}-\mathrm{Ex})$

${ }^{* * *} \mathrm{P}<0.01 ;{ }^{* *} \mathrm{P}<0.05 ;{ }^{*} \mathrm{P}<0.10 ;{ }^{\text {ns }}=$ not significant;

Regression equations for Nitrogen:

Nutrients provided via fertilization: ns

Nutrients extracted by total biomass: ns

Nutrients contained in the remaining phytomass: $\mathrm{y}=-6.6 * * *+0.399 * * * \mathrm{x}\left(\mathrm{CV}: 20.6 \% ; \mathrm{R}^{2}: 0.92 ; \mathrm{P}=0.0001\right)$

Nutrients depleted by the ensilable phytomass: $\mathrm{y}=208.7^{* * *}-0.355^{* * *} \mathrm{x}\left(\mathrm{CV}: 9.7 \% ; \mathrm{R}^{2}: 0.25 ; \mathrm{P}=0.0108\right)$

Nutrient balance in the soil: $y=6.3^{\text {ns }}+0.355^{* * *} x\left(C V: 65.6 \% ; R^{2}: 0.25 ; P=0.0108\right)$

Regression equations for Phosphorus:

Nutrients provided via fertilization: ns

Nutrients extracted by total biomass: ns

Nutrients contained in the remaining phytomass: $\mathrm{y}=-1.2 * * *+0.067 * * * x\left(\mathrm{CV}: 28.6 \% ; \mathrm{R}^{2}: 0.86 ; \mathrm{P}=0.0001\right)$

Nutrients depleted by the ensilable phytomass: $\mathrm{y}=59.8^{* * *}-0.131^{* *} \mathrm{x}\left(\mathrm{CV}: 14.7 \% ; \mathrm{R}^{2}: 0.20 ; \mathrm{P}=0.0234\right)$

Nutrient balance in the soil: $\mathrm{y}=15.2 * * *+0.131 * * x\left(C V: 33.1 \% ; \mathrm{R}^{2}: 0.20 ; \mathrm{P}=0.0234\right)$

Regression equations for Potassium:

Nutrients provided via fertilization: ns

Nutrients extracted by total biomass: ns

Nutrients contained in the remaining phytomass: $\mathrm{y}=-7.1^{*}+0.885^{* * *} \mathrm{x}\left(\mathrm{CV}: 22.4 \% ; \mathrm{R}^{2}: 0.87 ; \mathrm{P}=0.0001\right)$

Nutrients depleted by the ensilable phytomass: $\mathrm{y}=202.1 * * *-0.947 * * * x\left(\mathrm{CV}: 17.1 \% ; \mathrm{R}^{2}: 0.56 ; \mathrm{P}=0.0001\right)$

Nutrient balance in the soil: $\mathrm{y}=-127.1 * * *+0.95 * * * \mathrm{x}\left(\mathrm{CV}: 35.4 \% ; \mathrm{R}^{2}: 0.56 ; \mathrm{P}=0.0001\right)$

Regression equations for Calcium:

Nutrients provided via fertilization: ns

Nutrients extracted by total biomass: ns

Nutrients contained in the remaining phytomass: $\mathrm{y}=-2.6^{* *}+0.179 * * * \mathrm{x}\left(\mathrm{CV}: 30.7 \% ; \mathrm{R}^{2}: 0.82 ; \mathrm{P}=0.0001\right)$

Nutrients depleted by the ensilable phytomass: $\mathrm{y}=24.9 * * *-0.089 * * * x\left(\mathrm{CV}: 12.4 \% ; \mathrm{R}^{2}: 0.54 ; \mathrm{P}=0.0001\right)$

Nutrient balance in the soil: $\mathrm{y}=-24.9 * * *+0.09 * * * x\left(C V: 12.4 \% ; \mathrm{R}^{2}: 0.54 ; \mathrm{P}=0.0001\right)$

Regression equations for Magnesium:

Nutrients provided via fertilization: ns

Nutrients extracted by total biomass: ns

Nutrients contained in the remaining phytomass: $\mathrm{y}=-0.1^{\mathrm{ns}}+0.175^{* * *} \mathrm{x}\left(\mathrm{CV}: 25.7 \% ; \mathrm{R}^{2}: 0.79 ; \mathrm{P}=0.0001\right)$

Nutrients depleted by the ensilable phytomass: $\mathrm{y}=43.8 * * *-0.122 * * * x\left(\mathrm{CV}: 10.5 \% ; \mathrm{R}^{2}: 0.47 ; \mathrm{P}=0.0002\right)$

Nutrient balance in the soil: $\mathrm{y}=-43.8 * * *+0.12 * * * x\left(C V: 10.5 \% ; \mathrm{R}^{2}: 0.47 ; \mathrm{P}=0.0002\right)$. 
Table 7. Economic analysis of maize cultivation for silage production, considering the return of nutrients to the soil through the remaining biomass in addition to fertilization, and estimation of milk production by silage.

\begin{tabular}{|c|c|c|c|c|c|}
\hline \multirow{2}{*}{ Parameters of economic analysis } & \multicolumn{5}{|c|}{ Cutting heights (cm) } \\
\hline & 20 & 40 & 60 & 80 & 100 \\
\hline \multicolumn{6}{|c|}{ Silage production cost from planting to storage $\left(\mathrm{R} \$ \mathrm{ha}^{-1}\right)$} \\
\hline Total cost of silage production & $4,001.94$ & $4,001.94$ & $4,001.94$ & $4,001.94$ & $4,001.94$ \\
\hline \multicolumn{6}{|c|}{ Values of the nutrients remaining in the soil through the remaining biomass $\left(\mathrm{R} \$ \mathrm{ha}^{-1}\right)$} \\
\hline Remaining $\mathbf{N}$ & 9.89 & 28.80 & 51.46 & 73.98 & 116.00 \\
\hline Remaining $\mathrm{P}_{2} \mathrm{O}_{5}$ & 3.15 & 7.56 & 13.61 & 23.35 & 35.41 \\
\hline Remaining $\mathrm{K}_{2} \mathrm{O}$ & 35.69 & 66.20 & 116.01 & 181.90 & 213.79 \\
\hline Total remaining NPK & 48.74 & 102.57 & 181.08 & 279.23 & 365.20 \\
\hline Cost of production without remaining content ${ }^{\mathrm{a}}$ & $3,953.20$ & $3,899.37$ & $3,820.86$ & $3,722.71$ & $3,636.74$ \\
\hline \multicolumn{6}{|c|}{ Parameters of silage production } \\
\hline Dry biomass production $\left(\mathrm{kg} \mathrm{ha}^{-1}\right)$ & 15.979 & 15.719 & 15.205 & 14.589 & 13.157 \\
\hline Estimates of milk production $\left(\mathrm{kg} \mathrm{ha}^{-1}\right)^{\mathrm{b}}$ & 24.047 & 24.894 & 24.109 & 24.120 & 21.639 \\
\hline Estimates of milk production $\left(\mathrm{kg} \mathrm{t}^{-1}\right.$ of DM) ${ }^{\mathrm{c}}$ & 1.505 & 1.581 & 1.587 & 1.655 & 1.646 \\
\hline \multicolumn{6}{|c|}{ Silage costs $\left(\mathrm{R} \$ \mathrm{t}^{-1}\right.$ of $\left.\mathrm{DM}\right)$} \\
\hline Cost without nutrients from remaining biomass ${ }^{d}$ & 250.70 & 256.13 & 266.30 & 277.66 & 305.97 \\
\hline Cost with nutrients from remaining biomass ${ }^{e}$ & 247.64 & 249.65 & 254.18 & 258.54 & 278.22 \\
\hline $\begin{array}{l}\hat{y}=4049.451^{* * *}-4.0479 * * * x\left(C V: 0.99 \% ; R^{2}: 0.91 \mathrm{P}=0 .\right. \\
\hat{y}=22509.000^{* * *}+97.5942 x-1.0462 x^{2}\left(C V: 10.26 \% ; R^{2}: 0\right. \\
\hat{y}=1488.281^{* * *+1.7750 * * * x}\left(C V: 4.39 \% ; R^{2}: 0.36 \mathrm{P}=0 .\right. \\
\hat{y}=231.732 * * *+0.6604 * * * x\left(C V: 9.33 \% ; R^{2}: 0.37 \mathrm{P}=0.0\right. \\
\hat{y}=236.637 * * *+0.3502 * x\left(C V: 9.60 \% ; R^{2}: 0.15 \mathrm{P}=0.057\right.\end{array}$ & $\begin{array}{l}\mathrm{P}=0.1086) \\
\text { 16) } \\
\text { 2) }\end{array}$ & & & & \\
\hline
\end{tabular}

Rezende et al. (2015) found that the increase in the cost of maize for silage production made it unfeasible to increase the cutting height. However, these authors affirm that this increase is initial, and that taking into account the gain in meat and milk, and especially in the long-term cycling of nutrients to the soil, it is possible to revert the increase in the production cost with the final product.

A higher milk production is justified by the better nutritional quality of the silage with the increase in the cutting height. Thus, we performed an economic analysis of milk production per metric ton of DM. Indeed, we estimated that milk production increased linearly with the cutting height of maize for silage, with every $0.10 \mathrm{~m}$ increase in the cutting height yielding an additional $17.75 \mathrm{~kg}$ of milk t $\mathrm{t}^{-1}$ of DM. However, the estimates for milk production per hectare presented a quadratic response, with the highest milk production per hectare observed with silage harvested at $0.47 \mathrm{~m}$. Similar results were found by Caetano et al. (2005), who reported that the conversion of silage to milk tended to increase $(\mathrm{P}<0.08)$ for the silage produced with a cut at 0.31 $\mathrm{m}$ compared to that harvested at $0.10 \mathrm{~m}$. Neylon and Kung Junior (2003) observed an increase of 98 $\mathrm{kg} \mathrm{t}^{-1}$ in the milk yield per metric ton of silage when cutting height increased from $0.13 \mathrm{~m}$ to $0.46 \mathrm{~m}$, but no effect of a higher cutting height on milk yield per hectare $(\mathrm{P}<0.05)$. Lauer $(1998)$ showed that when the cutting height increased from $0.15 \mathrm{~m}$ to 0.45 $\mathrm{m}$, the estimated milk production per metric ton of silage increased by approximately $12 \%$. However, there was a $3 \%$ reduction in milk production per area due to the lower harvesting of phytomass.

The cutting height also influences food efficiency, which is higher when crops are harvested at higher heights, as in a study published by Oliveira et al. (2011). These authors harvested at $0.55 \mathrm{~m}$ and observed an improvement in food efficiency. In the average hybrids and cutting heights, productivity 
was estimated at $1,303 \mathrm{~kg}$ milk t$^{-1}$ silage, based on the DM. Thus, milk yield in $\mathrm{kg} \mathrm{ha}^{-1}(17,956 ; 16,819$; $17,791)$ was similar at the three cutting heights $(0.15,0.35$ and $0.55 \mathrm{~m}$, respectively).

In high-yielding herds with no restriction of fibrous food, it is recommended, based on the results presented previously, to harvest the silage at $0.45 \mathrm{~m}$. However, in medium to low-yield herds in which there is a food restriction, it is recommended to carry out the traditional harvest at $0,20 \mathrm{~m}$ from the soil.

\section{Conclusions}

Increasing the maize harvest height mitigated the depletion of soil nutrients, but did not prevent the potassium deficit in the system. Thus, potassium fertilization is still required in areas of silage production, considering the high decline of this nutrient in the soil.

The increase in harvest height improved the nutritional quality of the silage, but also promoted a reduction in the volume of forage harvested, linearly increasing the cost of food production. The choice of harvest height should depend on the purpose of sillage production. Where sillage is destined for supplementation in times of scarcity, the maximum amount of forage should be harvested to dilute the cost of production; however, where the goal is maximizing the productive potential of the animals, harvesting around $0.40 \mathrm{~m}$ from the soil provides the best balance between quantity and quality of the silage.

\section{References}

ASSOCIATION OF OFFICIAL ANALYTICAL CHEMISTS - AOAC. Official methods of analysis. $16^{\text {th }}$ ed. Washington: AOAC, 1995. 2000 p.

BOLSEN, K. K. Silage technology. In: AUSTRALIAN MAIZE CONFERENCE, 2., 1996, Queensland. Proceedings... Queensland: Gatton College, 1996. p. $1-30$.
CAETANO, H.; OLIVEIRA, M. D. S.; FREITAS JÚNIOR, J. E.; RÊGO, A. C.; CARVALHO, M. V.; RENNÓ, F. P. Bromatological evaluation of eleven corn cultivars harvested at two cutting heights. Revista Brasileira de Zootecnia, Viçosa, MG, v. 41, n. 1, p. 1117, 2012.

CASTAÑEDA, F. G.; RAMOS, A. P.; HERNÁNDES, G. N. Efecto de la densidad y altura de colheita in el rendimiento y calidad del forraje de maíz. Revista Fitotecnia Mexicana, Chapingo, v. 28, n. 4, p. 393-397, 2005.

COMISSÃO DE QUÍMICA E FERTILIDADE DO SOLO - CQFS RS/SC. Manual de adubação e de calagem para os estados do Rio Grande do Sul e Santa Catarina. 10. ed. Porto Alegre: Sociedade Brasileira de Ciência do Solo/Núcleo Regional Sul, 2004. 400 p.

COMPANHIA NACIONAL DE ABASTECIMENTO - CONAB. Acompanhamento da safra brasileira de grãos: safra 2014/2015. Brasília: CONAB, 2015. Disponível em: <http://www.conab.gov.br/OlalaCMS/ uploads/arquivos/15_05_13_08_46_55_boletim_graos_ maio_2015.pdf. $>$. Acesso em: 9 jun. 2015.

. Custo de produção - culturas de verão: milho - plantio direto - alta tecnologia. Brasília: CONAB, 2016a. Disponível em: <http://www.conab.gov.br/ conteudos.php? $\mathrm{a}=1276 \&$ ordem $=$ titulo\&Pagina objcmsconteudos $=3 \#$ A_objcmsconteudos $>$. Acesso em: 10 out. 2016.

.Produtos e serviços - indicadores da agropecuária: preços dos insumos agropecuários. Brasília: CONAB, 2016b. Disponível em: <http://www.conab.gov.br/ detalhe.php? $\mathrm{a}=1303 \& \mathrm{t}=2>$. Acesso em: 10 out. 2016.

EMPRESA BRASILEIRA DE PESQUISA AGROPECUÁRIA - EMBRAPA. Sistema brasileiro de classificação de solos. 2. ed. Rio de Janeiro: Embrapa Solos, 2006. 306 p.

Sistema de produção de leite (Zona da Mata Atlântica) - coeficiente técnico: custo de produção de silagem de milho. Juiz de Fora: EMBRAPA Gado de Leite, 2003. Disponível em: <http:// sistemasdeproducao.cnptia.embrapa.br/FontesHTML/ Leite/LeiteZonadaMataAtlantica/custos/cpsilagemilho. html>. Acesso em: 10 out. 2016.

GOERING, H. K.; VAN SOEST, P. J. Forage fiber analysis: apparatus reagents, procedures and some applications. Washington: Agricultural Handbook, 1970. $379 \mathrm{p}$.

INSTITUTO AGRONÔMICO DO PARANÁ - IAPAR. Cartas climáticas do Paraná. Versão 1.0. Londrina: IAPAR, 2000. CD-ROM 
JUREMTCHUK, A. R.; COSTA, C.; MEIRELLES, P. R. L.; GONÇALVES, H. C.; OSTRENSKY, A.; KOSLOWSKI, L. A.; MADEIRA, H. M. F. Produção, composição bromatológica e extração de potássio pela planta de milho para silagem colhida em duas alturas. Acta Scientiarum Agronomy, Maringá, v. 28, n.3, p. 351357, 2006.

KUNG JUNIOR, L.; MOULDER, B. M.; MULROONEY, C. M.; TELLER, R. S.; SCHMIDT, R. J. The effect of silage cutting height on the nutritive value of a normal corn silage hybrid compared with Brown Midrib corn silage fed to lactating cows. Journal of Dairy Science, Newark, v. 91, n.4, p. 1451-1457, 2008.

LAUER, J. Corn silage cutting height. Madison: University of Wisconsin - Extension, Agronomy Advice, 1998. Available at: <http://www.uwex.edu/ces/forage/ wfc/proceedings2001/corn_silage_cutting height.htm>. Accessed at: 30 jan. 2014.

MAACK, R. Geografia física do Estado do Paraná. 3. ed. Curitiba: Imprensa Oficial, 2002. 438 p.

MARTIN, T. N.; PAVINATO, P. S.; SILVA, M. R.; ORTIZ, S.; BERTONCELI, P. Fluxo de nutrientes em ecossistemas de produção de forragens conservadas. In: SIMPÓSIO: PRODUÇÃO E UTILIZAÇÃO DE FORRAGENS CONSERVADAS, 4., 2011, Maringá. Anais... Maringá: Sthampa, 2011. p. 173-220.

NEUMANN, M.; MÜHLBACH, P. R.; RESTLE, J.; OST, P. R.; LUSTOSA, S. B. C.; FALBO, M. K. Ensilagem de milho (Zea mays L.) em diferentes alturas de colheita e tamanho de partículas: produção, composição e utilização na terminação de bovinos em confinamento. Revista Brasileira de Milho e Sorgo, Sete Lagoas, v. 6, n. 3, p. 379-397, 2007.

NEYLON, J. M.; KUNG JUNIOR, L. Effects of cutting height and maturity on the nutritive value of corn silage for lactating cows. Journal of Dairy Science, Newark, v. 86, n. 6, p. 2163-2169, 2003.

NUSSIO, L. G.; CAMPOS, F. P.; DIAS, F. N. Importância da qualidade da porção vegetativa no valor alimentício da silagem de milho. In: SIMPÓSIO SOBRE PRODUÇÃO E UTILIZAÇÃO DE FORRAGENS CONSERVADAS, 1., 2001, Maringá. Anais... Maringá: Universidade Estadual de Maringá, 2001a. p. 127-145.

NUSSIO, L. G.; ZOPOLLATO, M.; MOURA, J. C. Metodologia de avaliação e aditivos. In: WORKSHOP SOBRE MILHO PARA SILAGEM, 2001, Piracicaba. Anais... Piracicaba: FEALQ, 2001b. p. 1-127.

OLIVEIRA, F. C. L. Produtividade e valor nutritivo das silagens e composição mineral da forragem remanescente e híbridos de milho colhidos em diferentes alturas. 2009. Dissertação (Mestrado em Zootecnia) - Universidade Estadual de Maringá, Maringá.

OLIVEIRA, F. C. L.; JOBIM, C. J.; SIMILI, M. S.; CALIXTO JUNIOR, M.; BUMBIERIS JUNIOR, V. H.; ROMAN, J. Produtividade e valor nutricional da silagem de híbridos de milho em diferentes alturas de colheita. Revista Brasileira de Zootecnia, Viçosa, MG, v. 40, n. 4, p. 720-727, 2011.

PARANÁ. Secretaria da Agricultura e do Abastecimento do Estado do Paraná. Pesquisa de preços pagos pelos produtores. Curitiba: Departamento de Economia Rural DERAL, 2016. Disponível em: $<$ http://www.agricultura. pr.gov.br/>. Acesso em: 10 out. 2016.

PAZIANI, S. F.; DUARTE, A. P.; NUSSIO, L. G.; GALLO, P. B.; BITTAR, C. M. M.; ZOPOLLATTO, M.; RECO, P. C. Características agronômicas e bromatológicas de híbridos de milho para produção de silagem. Revista Brasileira de Zootecnia, Viçosa, MG, v. 38, n. 3, p. 411-417, 2009.

PEDÓ, L. F. B.; NÖRNBERG, J. L.; VELHO, J. P.; HENTZ, F.; HENN, J. D.; BARCELLOS, J. O. J.; VELHO, I. M. P. H.; MARX, F. R. Fracionamento de carboidratos de silagens de milho safrinha colhidos em diferentes alturas de colheita. Ciência Rural, Santa Maria, v. 39, n. 1, p. 188-194, 2009.

PORTER, M. G.; MURRAY, R. S. The volatility of components of grass silage on over drying and the interrelationship between dry-matter content estimated by different analytical methods. Grass and Forage Science, Oxford, v. 56, n. 4, p. 405-411, 2001.

RESTLE, J.; NEUMANN, M.; BRONDANI, I. L.; ALVES FILHO, D. C.; BERNARDES, R. A. C.; ARBOITTE, M. Z.; ROSA, J. R. P. Manipulação do corte do sorgo (Sorghumbicolor, L. Moench) para confecção de silagem, visando a produção do novilho superprecoce. Revista Brasileira de Zootecnia, Viçosa, MG, v. 31, n. 3, p. 1481-1490, 2002a.

RESTLE，J.; NEUMANN, M.; BRONDANI, I. L.; PASCOAL, L. L.; SILVA, J. H. S.; PELLEGRINI, L. G.; SOUZA, A. N. M. Manipulação da altura de colheita da planta de milho (Zea mays, L.) para ensilagem, visando a produção do superprecoce. Revista Brasileira de Zootecnia, Viçosa, MG, v. 31, n. 3, p. 1235-1244, 2002 b.

REZENDE, A. V. D.; WATANABE, D. J.; SILVEIRA RABELO, F. H.; SILVEIRA RABELO, C. H.; NOGUEIRA, D. A. Características agronômicas, bromatológicas e econômicas de alturas de corte para ensilagem da cultura do milho. Semina: Ciencias Agrarias, Londrina, v. 36, n. 2, p. 961-970, 2015. 
RITCHIE, S. W.; HANWAY, J. J.; BENSON, G. O. Como a planta de milho se desenvolve. Piracicaba: Potafos: Arquivo do Agrônomo, 2003. n. 15, 20 p. (Informações Agronômicas, n. 103).

STATISTICAL ANALYSIS SYSTEM INSTITUTE SAS INSTITUTE. SAS/STAT user's guide: statistics, version 6. 4. ed. North Caroline: SAS Institute Inc, 1993. v. 2, 943 p.

SHAVER, R. D.; LAUER, J. G.; COORS, J. G.; HOFFMAN, P. C. Corn silage: calculates TDN-1x, NEL$3 \mathrm{x}$, milk per ton, and milk per acre. Madison: University of Wisconsin - Extension, 2006. Disponível em: <http:// www.uwex.edu/ces/dairynutrition/spreadsheets.cfm>. Acesso em: 30 maio 2014.

SILVA, J. C. P. M.; MOTTA, A. C. V.; PAULETTI, V.; VELOSO, C. M.; FAVARETTO, N.; BARCELLOS, M.; OLIVEIRA, A. S.; SILVA, L. F. C. Esterco de gado leiteiro associado à adubação mineral e sua influência na fertilidade de um latossolo sob plantio direto. Revista Brasileira de Ciência do Solo, Viçosa, MG, v. 34, n. 2, p. 453-463, 2010.

SILVA, D. J.; QUEIROZ, A. C. Análise de alimentos, métodos químicos e biológicos. 3. ed. $4^{\mathrm{a}}$ reimpressão. Viçosa: Universidade Federal de Viçosa, 2009. 235 p.

TEDESCO, M. J.; GIANELlO, C.; BISSANI, C. A.; BOHNEN, H.; VOLKWEISS, S. J. Análises de solo, plantas e outros materiais. 2. ed. Porto Alegre: Universidade Federal do Rio Grande do Sul, 1995. 174 p. (Boletim técnico, n. 5).

UENO, R. K.; NEUMANN, M.; MARAFON, F.; REINEHR, L. L.; POCZYNEK, M.; MICHALOVICZ, L. Exportação de macronutrientes do solo em área cultivada com milho para alimentação de bovinos confinados. Semina: Ciências Agrarias, Londrina, v. 34, n. 6, p. 3001-3018, 2013.

VALADARES FILHO, S. C.; MAGALHÃES, K. A.; ROCHA JUNIOR, V. R. Tabelas brasileiras de composição de alimentos para bovinos. CQBAL 2.0. 2. ed. Viçosa, MG: Universidade Federal de Viçosa; Suprema Gráfica Ltda, 2006. 329 p.

VAN SOEST, P. J. Nutritional ecology of the ruminant. $2^{\text {th }}$ ed. New York: Cornell University Press, 1994. 476 p.

VAN SOEST, P. J.; ROBERTTSON, J. B.; LEWIS, B. A. Methods for dietary fiber, neutral detergent fiber, and nonstarch polysaccharides in relation to animal nutrition. Journal of Dairy Science, Champaign, v. 74, n. 10, p. 3583-3597, 1991.

VASCONCELOS, R. C.; VON PINHO, R. G.; REZENDE, A. V.; PEREIRA, M. N.; BRITO, A. H. Efeito da altura de colheita das plantas na produtividade de matéria seca e em características bromatológicas de forragem de milho. Ciência e Agrotecnologia, Lavras, v. 29, n. 6, p. 1139-1145, 2005.

VON PINHO, R. G.; BORGES, I. D.; PEREIRA, J. L. A. R.; REIS, M. C. Marcha de absorção de macronutrientes e acúmulo de matéria seca em milho. Revista Brasileira de Milho e Sorgo, Sete Lagoas, v. 8, n. 2, p. 157-173, 2009.

WEISS, W. P.; CONRAD, H. R.; ST PIERRE, N. R. A theoretically based model for predicting total digestible nutrient values of forages and concentrates. Animal Feed Science and Technology, Benin, v. 39, n. 1, p. 95-110, 1992. 
